

\title{
THERAPEUTIC IMPORTANCE OF PANCHAKARMA W.S.R. TO VAMANA AND VIRECHANA KARMA: AN AYURVEDA REVIEW
}

\section{Rishi Mishra*1 and Sanjeev Madhukarrao Khuje ${ }^{2}$}

${ }^{1 *}$ Department of Panchakarma, Rajeev Gandhi Ayurved College and Hospital, Bhopal, Madhya Pradesh, India.

${ }^{2}$ Rog Nidan Evam Vikriti Vigyan, Government (Autonomous) Ayurved College, Rewa, Madhya Pradesh, India.

\section{ABSTRACT}

Panchakarma is one of the important therapies of Ayurveda science which eliminate excessive Doshas, maintain good health states and cure many diseases. Panchakarma therapy encompasses many modalities Vamana and Virechana are some of them. Virechana mainly helps in the elimination of Pitta Dosha and treat disorders related to gastric system and skin diseases. Vamana also helps to cure problem related to Kapha and Pitta dosha. Vamana helps in Pandu, Prameha, Unmada and also offers therapeutic benefits in respiratory problems. Considering therapeutic importance of Vamana and Virechana Karma present article explored Ayurveda perspective on both therapies.

\section{KEYWORDS}

Ayurveda, Panchakarma, Vamana and Virechana.

\section{Author for Correspondence:}

Rishi Mishra,

Department of Panchakarma,

Rajeev Gandhi Ayurved College and Hospital,

Bhopal, Madhya Pradesh, India.

Email: bhadoriyaupendra@yahoo.co.in

Available online: www.uptodateresearchpublication.com

\section{INTRODUCTION}

Ayurveda the ancient system of healthy regimen described many therapeutic modalities for the management of different health ailments and Panchakarma is one of them. Panchakarma mainly considered as detoxification measures which offers several health benefits. Panchakarma can be done by performing five detoxification procedures including Vamana and Virechana Karma. Vamana and Virechana Karma are two major process of Panchakarma which provide therapeutic benefits in many illnesses. These therapies provides Dahana and Swedana effects, facilitates Chedana of Doshas, causes Vishayandana of Doshas, open up micro 
channels and ultimately facilitate expulsion of morbid Doshas \& toxins. Panchakarma must be performed with great care otherwise some complications may arise as depicted in Figure No.1.

\section{Biological actions of Vamana}

- Vamana expelled out undigested food and toxins from body.

- Removes excessive Kapha Dosha and Pitta dosha.

- Vamana eliminate vitiated Kapha Dosha.

- Vamana opens Srotas/micro channels thus boost circulation.

- Vamana reduces swelling and edema.

- Vamana pacifies Rakta Dhatu Dushti.

Therapeutic importance of Vamana

- Mridu Vamana helps in Yakshma, Gulma, Shwasa, Hikka, Kaphavruttavata, Pandu and Vatarakta.

- Tikshna Vamana offers benefits in Murchchha, Prameha, Pidika and Unmada.

- Vamana reduces itching and inflammation thus cures pathogenesis of skin disease.

- Vamana Karma helps to treat Viddha and Vishapita.

- It also recommended in Kushta and Raktapitta due to its detoxification actions etc.

- Vamana can manage Hypothyroidism and Pratishyaya.

- Vamana eliminates Kleda thus helps in diabetes.

- Vamana pacify Ama thus cure digestive and metabolic abnormalities.

\section{Mechanism of Vamana Karma}

Vamana Yoga may comprise of Saindhava, Madanphala Pippali, Vacha Churna and Madhu. Vamaka dravyas quickly absorbed stimulates vomiting. Vamaka dravyas possess Tikshana, Sukshama, Usna, Urdhavabhagha prabhava and Vikasi properties. Vikashi and Vyavayi properties of Vamaka dravyas facilitate drug transportation through micro channels, there after these drugs liquefies Dosha Samghata due to their Ushana guna and break up accumulated Dosha by virtue of their Tikshana Guna, after that vitiated Pitta dosha and toxins expelled out from body under the influence of kinetic movement of emesis.

\section{Biological actions of Virechana}

- Facilitate bowel movement and its evacuation

- Virechana pacify vitiated Pitta Dosha and expelled them

- Imparts osmotic action

- Increase colonic content and propelled it

- Removes Ama and undigested food

- Clears blockage of channels

\section{Therapeutic importance of Virechana}

- Removes toxins thus offers benefits in skin diseases.

- Can help to cure chronic fever.

- Cures some anorectal disorders like hemorrhoids.

- Relief edema thus helps in Gulma.

- It can be used effectively for the management of Splenomegaly and Hepatomegaly.

- Removes toxins from stomach and clears lever passage thus helps in the management of Jaundice.

- Virechana relieve symptoms of Gout and arthritis.

- Virechana helps in the management of food poisoning and drug overdosing.

\section{Mechanism of Virechana Karma}

Virechana drugs facilitate evacuation of bowel thus enhances process of defecation thereby causes detoxification through intestinal/anal route. Virechana drugs spread throughout the body due to their Vyavayi properties. Ushna property causes Vishyandana effects; Tikshna properties drugs leads Chedana of vitiated Doshas, Virechana disintegrate the Sanghata of Dosha. Facilitate downward kinetic movement of Doshas towards the Koshtha from there these morbid Doshas and toxins get eliminated. Adhobhaga hara Prabhava effect of therapy facilitates expulsion of vitiated Doshas through Guda.

Drugs

- Pippali, Sunthi and Maricha can be used prior to Snehapana. 
- Haritaki, Bibhitaka, Aamalaki, Aaragvadha, Patha, Vatsaka and Nimba can be used for Aabhyantara Snehapana.

- Ikshwaku with and Saindhavalavana can be used for Vamana.

- Madhuyasti can also used for this purpose.

- Katuki Choornacan be used for Virechana Karma.

Desirable properties of drugs used for Vamana and Virechana Karma

- Drug should be in edible form.

- Non toxic and work in small dosage.
- Must offers quick action.

- Palatable and easy to administer.

- Should not induce severe complication.

- Non allergic and acceptable in all terms.

Contraindication of Vamana and Virechana Karma

- Childhood and elder person

- Acute fever and dehydration

- Weakness and emaciation

- Bleeding conditions

- Prolapsed rectum and surgical pathogenesis

- Pregnancy



Figure No.1: Complications related to the adverse effects of Panchakarma

\section{CONCLUSION}

Panchakarma is detoxification therapy of Ayurveda encompasses different modalities; Vamana and Virechana are some of them which eliminate excessive Doshas, maintain circulatory process of body, expelled out undigested food, removes excessive Kapha Dosha, opens Srotas, reduces swelling and edema. These therapies pacify Rakta Dhatu Dushti, helps in disorders related to gastric system and skin diseases. Dahana, Swedana, Chedana of Doshas and Vishayandana of Doshas, etc. are some biological responses of Vamana and Virechana. These procedures can be used to treat diseases including Pidaka, Visarpa, Kamala, Pandu and Shopha, etc.

\section{ACKNOWLEDGEMENT}

The authors are sincerely thankful to Department of Panchakarma, Rajeev Gandhi Ayurved College and Hospital, Bhopal, Madhya Pradesh, India for providing the facilities to carry out this review work.

\section{CONFLICT OF INTEREST}

We declare that we have no conflict of interest.

\section{BIBLIOGRAPHY}

1. Sushruta Samhita. Eng translation, $P . V$. Sharma, Chaukhamba Visvabharti, Varanasi, 1-3, $1^{\text {st }}$ Edition, 1999.

2. Astanga Samgraha. Eng translation, $K$. R. Srikanthamurthy, Chaukhamba Orientalia, Varanasi, 2, $3^{\text {rd }}$ Edition, 2000. 
Rishi Mishra and Sanjeev Madhukarrao Khuje. / International Journal of Medicine and Health Profession Research. 7(1), $2020,5-8$.

3. Aacharya Jadavaji T. Chaukhambha Orientalia, Charak Samhita, Ayurveda dipika Commentary of Chakrapanidatta, Sutrasthan, 2007, 46.

4. Aacharya Jadavaji T. Chaukhambha Orientalia, Charak Samhita, Ayurveda dipika Commentary of Chakrapanidatta, Sutrasthan, 2007, 97.

5. Aacharya Jadavaji T. Chikitsasthan. Chaukhambha Orientalia, Charak Samhita, Ayurveda Dipika Commentary of Chakrapanidatta, 2007, 337.

6. Pandya D. Sutrasthan. Saraswati Pustak Bhandar, Ashtang Hridaya, Ahmadabad, $2^{\text {nd }}$ Edition, 1999, 253.

7. Agnivesha, Charaka, Charaka Samhita. Vaidya Yadavaji Trikamji Acharya reprint, Chaukhamba Surbharati Prakashana, Varanasi, Chikitsa Sthana, 17/90, 2011, 537.

8. Vaidya Yadavaji Trikamji, Acharya Sushruta, Shushruta Samhita. Uttartantra 24/17, Chaukhambha Surbharati Prakashan, Varanasi, 2010, 652.

9. Santoshkumar Bhatted. A study on Vasantika Vamana (therapeutic emesis in spring season) Apreventive measure for diseases of Kapha origin, Ayu, 32(2), 2011, 181-186.

Please cite this article in press as: Rishi Mishra and Sanjeev Madhukarrao Khuje. Therapeutic importance of Panchakarma W.S.R. to Vamana and Virechana Karma: An Ayurveda review, International Journal of Medicine and Health Profession Research, 7(1), 2020, 5-8. 